\title{
The Students' Problems and Solutions in Writing an Argumentative Essay on Gender Issue
}

\author{
Lestari Setyowati \\ University of PGRI Wiranegara \\ lestari.setyowati@yahoo.co.id \\ Fadiah Agustina \\ University of PGRI Wiranegara \\ fadiahagustina@gmail.com \\ Sony Sukmawan \\ University of Brawijaya \\ sony_sukmawan@ub.ac.id. \\ Ana Ahsana El-Sulukiyyah \\ University of PGRI Wiranegara \\ aahsana3@gmail.com \\ Barotun Mabaroh \\ University of PGRI Wiranegara \\ barotunmabaroh@yahoo.com
}

\begin{abstract}
This study is intended to find out the students' problems and their solutions in writing argumentative essays. The subjects of this study were the fourth-semester students of English Education study program, Faculty of Pedagogy and Psychology, University of PGRI Wiranegara in the academic year 2019-2020. This study used Byrne's classification in 1995 about writing problems, namely psychological, linguistic, and cognitive. This uses descriptive quantitative design. The instruments were documentation of the students' writing tasks and interviews. The result shows the almost all students have no problems in making thesis statements and refutations for their argumentative essay regarding gender issue. The
\end{abstract}




\section{Lestari Setyowati et al.}

students' psychological problems are anxiety, nervousness, the feeling of pressure in timed writing and perfect work, a negative expectation in writing, and low self-confidence. For the linguistic problems, the result from both data indicated that students faced problems in tenses, word-class, word formation, the use of the article, and word error. While the cognitive problems faced by the students are being ignorant in the use of punctuation, short knowledge in giving appropriate examples and details in the body of the essay, and lack of knowledge in writing reference. The solutions proposed by the students, among others are to have more readings on the topic, to be self-motivated learners, to propose untimed writing to the lecturer, and to use writing tools applications.

Keywords: argumentative essay, psychological, linguistic, cognitive, problems

\section{INTRODUCTION}

The issue of gender inequality is still prevalent until today. Despite of the fact that women can take part in the productivity and the enhancement of economic growth, full equality between men and women is still far from expectation (United Nation, in press). As quoted from the official site of the United Nation (in press), gender is named as one of the global issues the world face nowadays. The United Nations' Chapter 1 (Chapter 1, in press) states that one of the purpose of the $\mathrm{UN}$ is to "achieve international cooperation....in promoting and encouraging respect for human rights and for fundamental freedoms for all without distinction as to race, sex, language, or religion." This shows that the United Nations supports the women's rights. In Indonesia, the awareness of the concept of gender equality is still low even though it is widely practice in the society (Qomariah, 2019). Therefore, it is considered necessary to instill gender equality values through education.

Within the field of English Language Teaching (ELT), the inclusion of gender issues is necessary to raise the awareness of gender-based problems. Islam (2018) states that integrating gender contents into the ELT classrooms, especially those in higher education, may trigger the awareness of women rights and empowerment. He further states that the key success to any democratic society is gender equality and a discrimination free environment. Research on gender related issues in ELT are mostly about how they are manifested in the ELT classrooms (Sunderland, 1992), how ELT teachers address gender in their classrooms (Norton, \& Pavlenko, 2004), and how the language in the instructional materials depicts gender (Aydinoglu, 2014). Research on foreign language learners' (EFL) problems when writing essay on gender issues is still scarce. Raising gender issues for essay writing is necessary based on the following reasons. Firstly, gender inequality still occurs in Indonesia. Data from Directorate of Demography, Women Empowerment, and Child protection of Indonesia shows that there is still a problem in the development of gender equality and women empowerment in Indonesia as seen in the gender gaps in various fields of life (The Ministry of Demography, Women Empowerment, and Child protection of Indonesia/Bappenas, 2014). And secondly, understanding the students' problems when writing essays, especially the type of essay that raise higher order thinking such as an argumentative essay, benefits both the lecturer and the students. The lecturers can help the 
students to solve their problems in writing. While for the students, they can have more awareness of gender issues and have more critical thinking skill.

Writing is a productive skill which represents someone's thought. The process of making writing is different for each person because it requires an individual thought then modifies them into a structured result. According to Setyowati, Sukmawan, El-Sulukiyyah (2020), the students at the university level must have good writing skills. It is because almost every task is completed in the form of written documents, such as papers, articles, reports assignments, final projects, and thesis.

Writing is considered the most complex skill to learn among other skills. It is supported by Setyowati (2016) who states that writing has many elements that must be considered by the writer to be able to produce a piece of good writing, namely clear purpose, organization, word choice, language use, and ideas. The writer should formulate the whole elements of writing well. Furthermore, Rivers (1981: 294) claimed that writing in the language becomes a complicated activity because writing involves meaningful segments of language: words, sentence, grammar, and how to transfer those segments into written forms.

An argumentative essay is different from any other type of essay. One of the distinctive feature of argumentative essay is it contains refutation (rebuttal) and the essay itself is filled with the writer's argument (Setyowati, Sukmawan, El-Sulukiyyah, 2020). This essay requires strong and logical reasons to persuade readers (Davis \& Liss, 2005: 92). Thus, a critical thinking skill is needed in making an argumentative essay. Furthermore, writing an argumentative essay is not an easy thing to do. The students may face some problems in writing an argumentative essay. As stated by Ka-kan-dee \& Kaur (2015), argumentative is challenging for both second language learners (ESL) and foreign language learners (EFL). Moreover, Nippold \& Ward-Lonergan (2010: 238) point out that writing in an argumentative genre is a challenging communication task that requires sophisticated cognitive and linguistic abilities.

The problems of writing can be caused by anxiety or apprehension. According to Cheng (2004:319) writing anxiety is defined as a relatively stable anxiety disposition associated with L2 writing, which contains a variety of dysfunctional thoughts, increased physiological arousal, and maladaptive behaviors. Toba, Noor, \& Sanu (2019: 69) revealed that one of the identified problems of the Indonesian EFL students is the feeling of anxiety when writing in English. It appears because of their negative perception of writing. Cheng (2004) further mentioned that writing anxiety is divided into three types namely cognitive anxiety, somatic anxiety, and avoidance anxiety. He also states that cognitive anxiety refers to the cognitive aspect of anxiety experience, including negative expectations, preoccupation with performance, and concern about others' perceptions. Further, he states that somatic anxiety refers to one's perception of the psychological effects of the anxiety experience, such as nervous and tense. And the last, avoidance anxiety is a type of anxiety where the students avoid writing.

The problems which mostly faced by the EFL university students in Indonesia are such as generating ideas, planning, developing the thesis statement, and persuading the readers through a refutation. According to Ka-kan-dee and Kaur (2015: 154), the students encountered difficulties in putting together organized ideas and producing solid evidence necessary to write a well-organized essay. Moreover, one of the distinguishing features of 


\section{Lestari Setyowati et al.}

the argumentative text which is considered as a challenge in mastering this text is a refutation (Sukmawan, Setyowati, \& Nurmansyah, 2017). Refutation is used to persuade readers about the writer's opinion (Setyowati, Sukmawan, \& El-Sulukiyyah, 2020). Furthermore, the importance of argumentative writing for college students is to help the college students in developing their critical thinking, the ability to examine, and their logical thinking's competence (Sukmawan, Setyowati, \& Nurmansyah, 2017). Aunurrahman, Hamied, \& Emilia (2016) pointed out that the EFL students' writing control related to the structures and linguistic features in argumentative essay writing was still limited, especially in developing critical thinking. The evidence seems to indicate that Indonesian students' problems can be categorized into linguistics and cognitive problems. Moreover, Byrne (1995) classified the problems in writing into three; those are psychological problems, linguistic problems, and cognitive problems.

As in college level most assignments are in the form of papers and written documents, it is important for university students to master this type of writing genre. The essay writing course is typically offered to English education department students in their second years of study and often becomes a prerequisite for them to take. Similar case occurs in the fourth semester students in English Education Study program in the Faculty of Pedagogy and Psychology, University of PGRI Wiranegara, Pasuruan, East Java, Indonesia.The English Education department students are required to take the essay writing course in their fourth semester. This particular student becomes unique because in the academic year 2019 and 2020, they become the subjects of a grant research focusing on their essay writing performance. Thus, this study is aimed at finding out the students' problems in writing an argumentative essay in terms of their psychological problems, linguistics problems, and cognitive problems. This study also explores the students' solutions to overcome their problems.

\section{LITERATURE REVIEW}

\subsection{Essay Writing}

Writing is one of the English skills which delivers an idea or information into an organized and systematic written form. As stated by Setyowati (2016: 79-80), writing is a skill that difficult to master since there are many elements that must be considered by the writer to be able to produce a piece of a good writing, namely clear purpose, organization, word choice, language use, and ideas. However, Writing is one of the productive English skills that should be masterly skilled by English as Foreign Language (EFL) students in Indonesia for both written communication and academic writing purposes, such as; letters, essays, papers, articles, journals, project reports, theses, etc (Toba, Noor, \& Sanu, 2019).

An essay is a part of academic writing. The essay is defined as several paragraphs which developed by giving sufficient details and examples. Ariyanti (2016) defines an essay as the product of academic writing where a writer should combine factual data and compare it to existing experts' theories. In addition, Bakry \& Alsamadani (2014) indicated that essay writing provides students' opportunities to build and develop critical thinking so that students are trained to make their own judgments, determine their writing styles, and pick out scientific diction for their academic writing task. 


\subsection{Argumentative Essay}

The argumentative essay is a kind of essay which provides an argument that functioned to defend the writer's opinion. According to Alvarez (2001), an argumentative essay is understood as a dynamic literacy practice where the author establishes a dialogic relationship with an audience defending a point of view and looking to convince, get an adhesion, or persuade. Specifically, argumentative writing is the process of making a claim, challenging it, supporting it with reasons, questioning the reasons, rebutting them, and finally reaching a conclusion (Kuhn, 1991). Thus, argumentative writing has been proven by researchers to be the most difficult model in writing since it is crucial for tertiary students to articulate their ideas in academically appropriate patterns and approaches (Ferretti, Andrews-Weckerly \& Lewis, 2007).

As a part of academic writing, an argumentative essay consists of three generic structures. Despite the generic structures itself, the argumentative essay also has the other features namely refutation and claims (Setyowati, Sukmawan, El-Sulukiyyah, 2020). Both of these features typically only found in the argumentative essay. According to Chala \& Chapeton (2013), generic structures of the argumentative essay are introduction, body, and the conclusion. Yet, the special feature is the refutation. Refutation is only found in an argumentative essay. Setyowati, Sukmawan, El-Sulukiyyah, (2020) state that to refute and to rebut have a similar meaning which is to overcome opposing evidence and reasoning by introducing other evidence and reasoning that will damage its effect. And the next feature of an argumentative essay is the claim. According to Qin \& Karabacak (2010), a claim is an assertion as a response to a contentious topic or problem. Setyowati, Sukmawan, ElSulukiyyah, (2020) state there are several types of claims. They are claims of fact or definition, claims of cause and effect, claims about value, and claims about solutions or policies.

\subsection{Problems in Writing}

As stated before, argumentative is the most difficult model in writing. Thus, the students probably face some problems in writing an argumentative essay. Byrne (1995) classified the students' problems in writing into three, those are psychological problems, linguistic problems, and cognitive problems. Linguistic problems occur within structuring sentences such as tenses, word class, using articles, word formation, and word error. Solikhah (2017) states that in a general sense, problems on linguistic may include: syntax, grammar, vocabulary, and mechanics. The problems in the linguistic, event occur parallel to the problems in developing rhetoric in an essay.

Psychological problems occur as it depends on the students' state which relates to their emotion in writing an argumentative essay (Byrne, 1995). Psychological problems can be related to the writing anxiety faced by the students. Writing anxiety is also defined as a label for one or a combination of feelings, beliefs, or behaviors that interfere with a person's ability to start, work on, or finish a given writing task that he or she is intellectually capable of doing (Al-Sawalha \& Chow, 2012). Meanwhile, cognitive problems relate to how to organize our ideas, using punctuation, addressing a topic, following a topic, following instructions, and directions. Moreover, Levine (1998) indicated that cognitive problems in writing are related to the trouble in generating ideas or elaborating on them, difficulty in 


\section{Lestari Setyowati et al.}

developing and organizing ideas, lack of opinion or sense, and the difficulty with writing tasks that require creativity and/or critical thinking.

\subsection{Overcoming Problems in Writing}

There are several ways to solve the students' problems in writing an argumentative essay. Rahmatunnisa (2014) revealed that students usually ask for feedback from the lecturer, do editing and revising, outlining, ask friends for being prove-reader, and read more for improving their vocabulary. Furthermore, Setyowati, Sukmawan, \& Latief (2017: 100) state that the provision of planning is helpful to improve the students' writing performance in an argumentative essay.

Rahmatunnisa (2014) conducted the study which aimed to find out the problems in writing an argumentative essay faced by Indonesian EFL Learners. She conducted the Byrne (1995) analysis of the three problems in writing. Ibnian (2017) conducted a study on the difficulties encountered by Jordanian EFL Learners. This study aimed to explore the difficulties that university students face when they write in English as a Foreign Language (EFL).

Next, Setyowati, Sukmawan, \& Latief (2017) conducted research to solve the students' problems in writing an argumentative essay through the provision of planning. The purpose of this study is to find out how different planning formats can improve EFL students' writing performance in argumentative essays. The result of the study shows that the use of planning is able to improve the students' ability in writing an argumentative essay.

\section{RESEARCH METHODS}

This study was conducted in descriptive quantitative research design. The subject of this study was the fourth-semester students of the English education study program at the University of PGRI Wiranegara Pasuruan, Indonesia. The subjects of this study are 30 students joining the essay writing course in the 2019-2020 academic year. The sources of data in this study were from the students' writing tasks and interviews. The students wrote about a gender issue. The topic was "Is it okay for women to work?" The students should respond to the issue and give their opinion whether they agreed or disagreed for women to take participation in the public sphere. The researcher used the students' writing tasks to analyze the linguistic and cognitive problems faced by the students. To find out the types of linguistic problems faced by the students, the researcher used the table by Rahmatunnisa (2014), namely tenses, word class, word formation, the use of article, and word error. While the interview was used as the supporting data to find out the students' psychological, linguistic, and cognitive problems and the solutions to overcome them.

The questions in the interview were prepared in advance based on the theme being investigated. The interview was conducted via a mobile phone. The researcher called the respondents one by one to gain the data. The interview was conducted approximately 15 minutes and recorded and transcribed by the researchers. The data from the interview was gained from the majority results by the students. The researchers interviewed all the students, but if most of the data from the interviewees had similar answer, the data collection would not be continued. For analyzing the data, the researcher used qualitative data analysis 
The Students' Problems and Solutions in Writing

proposed by Creswell (2012). The steps are: 1) collecting the data, 2) preparing the data for analysis, 3 ) reading through the data, and 4) coding the data for analysis.

\section{FINDINGS}

\subsection{The Students' Psychological Problems}

The result of the interviews with the fourth-semester students of the University of PGRI Wiranegara showed that the students did not have problems in making refutations and thesis statement for their essay. Their statements were confirmed by their essays. Almost all of them were able to state refutation in their argumentative essay regarding to gender issue.

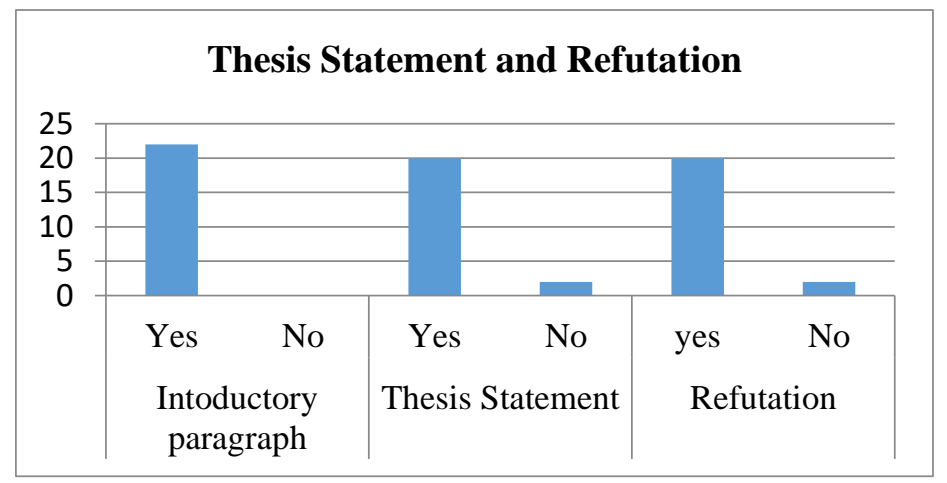

Figure 1. Thesis statement and Refutation in the Introductory Paragraph

Yet, they faced several psychological problems. The psychological problems occurred as the result of the students' state which related to the emotion when writing an argumentative essay. The psychological problems faced by the students are such as anxiety, nervousness, avoidance behavior, pressure in writing, negative expectation in writing, low self-confidence, feeling unable to give opinion and to think critically regarding to gender issue, and pressure for the perfect work. Writing an argumentative essay can cause anxiety since it is considered to be a very difficult kind of essay for the students.

"I often feel anxious when writing an argumentative essay. Sharing our opinion in an argument essay is more difficult than in other kinds of essay.” (M_18B).

The result of the interviews showed that the student felt nervous when writing an argumentative essay. One of the students mentioned that a limited time to finish writing could cause nervousness when writing an argumentative essay.

"I will feel nervous if I write for as an examination. Besides that, I feel nervous also if I am given limited time for writing an essay. But if I am given a long duration of time to write it, I think, I don't feel nervous." (SS_18A).

"I feel pressured in making an argumentative essay because in making an argumentative essay, I have to read a lot to get a lot of information and evidence that supports my essay. Whereas, I really do not like to read. but, I'm a perfectionist. So, I have to force myself to read in order to get good essays according to my standards." (SS_18A). 
To write well means to read well. Therefore, if a student wants to write a good essay, they need to read a lot. Yet, many students feel pressured when it comes to reading. The students also felt pressured to read a lot of references to support their arguments. This is because they do not like reading.

"I always feel pressured in writing an argumentative essay. I don't like to read, whereas in writing an argumentative essay we need proof that supports our opinion. Therefore, we are required to read a lot." (SS_18A)

Some of the students also feel not confident with their writing. They have a negative expectation because they doubt their writing skills.

"Yes, I have. I often have a negative expectation about my writing, I always think "Is it right or not? (I feel) my writing is bad because my writing skill is bad. (I feel) my writing is the worst in my class." (NK_18A).

A negative expectation in writing itself is included in cognitive anxiety which refers to the cognitive aspect of writing experience (Cheng, 2004). It is normal for the students to have a negative expectation in writing, especially for those who have low self-confidence. But the important thing is that the students should have the feeling of success of being able to accomplish the task regardless of being good or bad.

\subsection{The Students' Linguistic Problems}

The amount of students' writing task obtained by the researcher were 30 documents. The result of the students' linguistic problems illustrated by the following histogram.

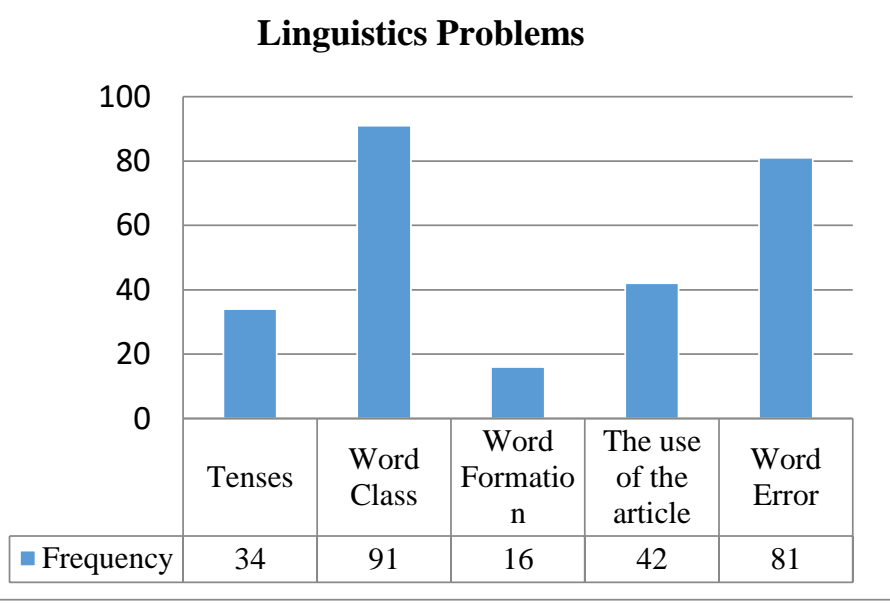

Figure 2. Linguistic Problems (Result from the Students' Task)

The figure showed the total frequency of linguistic problems faced by the fourthsemester students of the University of PGRI Wiranegara were 264 items with the classification as follows; tenses 34 items (13\%), word-class 91 items (34.4\%), word formation 16 items (6\%), the use of the article 42 items (16\%), and word error 81 items 
$(30.6 \%)$. The majority of linguistic problems faced by the students were word class with $34.4 \%$, while the fewer problems in linguistic were $6 \%$ which were from word formation. The students' problems in word-class were such as the wrong usage of prepositions, pronouns, determiners, and conjunctions. Whereas, for the problems in word formation were the conversion.

The interview's result shows that the linguistic problems faced by the students were only problems with tenses and using articles. The students' problems with tenses were: 1) the students are afraid to state the arguments or opinions by using the wrong tenses. And 2) the student accidentally changed the tenses from past to present. The next linguistic problem is problems in using articles. The result from the interview shows that some students confessed that they did not have problems in using articles. Yet, the data from the students' writing task show differently. The result showed that $16 \%$ of the students faced problems in using the articles. So, it means that the students did not realize of their error in using the articles.

\subsection{The Students' Cognitive Problems}

The result from the students' writing task shows that the students faced several cognitive problems in writing an argumentative essay. The students' cognitive problems were 1) using proper punctuation, 2) short knowledge in giving appropriate examples and details in the body of the essay, 3) unable to write references well. The researchers found that punctuation was the highest amount of cognitive problems faced by the students. The result showed that $80 \%$ of students faced the problem in using punctuation. The majority of punctuation that incorrectly used by the students was comma (,). For the other punctuation's problems were also found in the usage of the period (.), apostrophe ('), hyphen (-), and slash (/). The punctuation problem itself can be seen in almost in every of the students' essay.

The next cognitive problem is the short knowledge in the ideas development. They did not give appropriate examples and details in the body of the essay relevant to the topic. The result showed that $40 \%$ of students faced problems in organizing the ideas. Some of the supporting details in each paragraph are developed by the example and details. Yet, the details do not clearly support the thesis statement. The supporting details do not support the claims made by the students. And the final problem is the students did not know how to write references correctly. It was true that some students already stated the reference for their essay. But, the result from the students' writing showed that $46 \%$ of the students could not write the references properly. Some of the students only mentioned the references without writing the author, the title, and the year of publication.

\subsection{Solutions Proposed by the students}

Based on the interview, there were three solutions to overcome the students' psychological problems in writing an argumentative essay. The solutions were to read more journals and articles related to the topic, have self-motivation, asking for more time to finish the assignment, and use writing tools application.

$$
\text { Encourage and motivate ourselves when writing an argumentative essay }
$$
$\left(S S \_18 A\right)$. 


\section{Lestari Setyowati et al.}

Create a reward system after finishing to write an argumentative essay. This reward would make the students always be passionate in writing so that the students wouldn't feel lazy to write (SS_18A).

The students needed more time to deal with themselves before starting to write an argumentative essay ( $\left.A F_{-} 18 A\right)$.

Reading some journals or articles to know how to quote and make the references accurately (NK_18A)

Asking people who have much knowledge about argumentative essay. The people can be a lecturer or a senior at the college (SS_18A).

Using Grammarly to check the grammar and the other linguistic problems such as articles, word class, word formation, and word error (AF_18A).

Reading some articles to improve our arguments in writing an argumentative essay. The students read some articles for the references and learn from it to get useful information (NK_18A).

Be brave in making opinions and thinking critically about the topic given by the lecturer $\left(M_{-} 18 B\right)$.

These solutions are proposed by the students for themselves. It implies that the solution proposed by one student might not work for other student. Each of them believed that the proposed solution works best in one's situation and particular context.

\section{DISCUSSION}

From the findings above, it can be seen that the fourth-semester students still faced problems in writing an argumentative essay. Those problems were psychological, linguistic, and cognitive issues. Specifically, those three problems were varied since it dealt with the students' difficulty in writing an argumentative essay. The psychological problems faced by the students occurred as the result of the students' state which related to the emotion when writing an argumentative essay. The psychological problems in writing were related to anxiety (Al-Sawalha, \& Chow, 2012), nervousness, tense use, avoidance behavior (Cheng, 2004), and pressure in writing (Rezaei \& Jafari, 2014). Other psychological problems are the negative expectation in writing, low on self-confidence, and pressure for the perfect work (Wahyuni \& Umam, 2017). The findings in this study were also specified by Cheng (2004) that psychological effects in writing can be described as an undesirable feeling of tension and nervousness, cognitive interference in the writing process, and avoidance of writing.

In this study, the researchers also found that anxiety in writing is caused by the lack of grammar mastery. This is in line with the finding by Wahyuni \& Umam (2017) which states that language difficulties caused anxiety and make the students reluctant or lazy to write composition in English. Their finding also reveals that the difficulty in expressing ideas through correct and varied clauses which must be written according to grammar rules have caused anxiety. 
In terms of the nervousness in writing, the researchers found that the limited duration of writing makes the students uneasy. It is supported by Rezaei \& Jafari (2014) which states that the students cannot focus on the writing because the students concentrate on the limited time. Moreover, this study found that the student's negative expectations in writing were caused by the insecurities of other students' work. It is confirming the finding by Wahyuni \& Umam (2017) that the students can highly be effected by the expectation from the other students or teachers. The findings in this study proved that psychological problems faced by the students could not be underrated since the students' state or emotion affected the students' writing.

Linguistic problems faced by the students occurred within structuring sentences such as tenses, word class, and using articles. The results from the students' writing tasks and interviews were almost the same. The linguistic problems found from the writing tasks were tenses $(13 \%)$, word-class $(34.4 \%)$, word formation $(6 \%)$, the use of the article $(16 \%)$, and word error $(30,6 \%)$. The interview's result showed that the linguistic problems faced by the students were only problems with tenses and using articles. This finding means that the students only concerned about the tenses and articles without realizing that they made errors in the use of word class, and word formation. Furthermore, linguistic problems were the most problems faced by the students among others. This was in line with the previous study by Rahmatunnisa (2014) which stated that "linguistic" is the most common problems faced by the EFL students in writing.

The cognitive problems faced by the students relate to how to develop and organize the ideas, using punctuation, and addressing a topic. The students in this study also face similar problems. Some of the findings are also consistent with Ka-kan-dee \& Kaur (2015: 154) which states that the students encountered difficulties in putting together organized ideas and producing solid evidence necessary to write a well-organized essay. The finding of this study also supports Levine (1998) which indicates that cognitive problems in writing are related to the trouble in generating ideas or elaborating them. Other cognitive problems are lack of opinion or sense, and the difficulty with writing tasks that require creativity and/or critical thinking. In this present study, the cognitive problem which should be highlighted was the problem in writing references. Some of the students only write the hyperlink of the source of the reference without adding the writer, the year, and title of the source. It should be highlighted since reference is one of the important things which should be added to support the students' claim. The researchers also found some students who still used sources from Wikipedia and Blogspot to support their claim. As stated by Setyowati, Sukmawan, \& ElSulukiyyah (2020), the use of Wikipedia for academic writing should be avoided. This is all because the sources in Wikipedia is written and edited by many writers in which names, professions and affiliations are unknown by the audience. Instead of making strong arguments, using the source from Wikipedia only make the arguments invalid.

To overcome the problems, the students proposed solutions. Mostly, the solution to the psychological problem is self-motivated learning. The researchers believe that the most important thing to overcome the psychological problem is defeating the negative feeling within oneself. The students should deal with any kind of emotional state which will lead them to avoid writing. For the linguistic problem, the solutions are 1) reading some journals or articles to improve vocabulary and grammatical competence, 2) asking people who have 


\section{Lestari Setyowati et al.}

much knowledge about the argumentative essay, and 3) using writing tools assistance such as Grammarly. The researchers found out that Grammarly can be very useful for students to improve their writing skills. In Grammarly, the students are not only able to check the tenses, but also the other things related to linguistic aspects. Karyuatry, Rizqan, \& Darayani (2018) state that Grammarly can successfully enhance the students' writing quality. In relation to the cognitive problems, the researchers believe that using planning before writing is beneficial for the students. There are many different types of planning. The students may use explicit planning or 'implicit' planning (Setyowati, Sukmawan, \& Latief, 2017). One example of making explicit planning is by making web mapping, outlining, or listing. While the 'implicit' planning is one that employs free writing or drafting. The provision of planning is beneficial to improve the students' writing performance in writing an argumentative essay (Setyowati, Sukmawan, \& Latief, 2017). The students' preferences in planning will make the students more comfortable in generating ideas for the argumentative essay.

\section{CONCLUSION}

This study investigated the students' problems in writing an argumentative essay and the solutions to overcome the problems. The result yields that the students face psychological, linguistics, cognitive problem when writing an argumentative essay. Mostly, the students feel not confidence and feel a pressure when writing an argumentative writing. Yet, they have some solutions to overcome their problems. Among others are having a selfmotivated learning, reading a lot, and using writing tools application/assistance provided in the internet. If writing is a skill, then the most possible way to overcome the problem is by having a lot of practice. The saying of 'practice makes perfect' is undeniably true. Thus, to be able to write an argumentative essay well, the students should have a lot of practices. To do this, the students can join the lecturers to write for publication. Writing together for publication may help the students to have a clear purpose what to write, why write and how to write the text. Only when one has a clear purpose to write, all obstacles are overcome and defeated.

\section{ACKNOWLEDGEMENTS}

This research is fully supported by the Indonesian Directorate of Research and Community Engagement (DRPM) of Higher Education for funding in 2020.

\section{REFERENCES}

Al-Sawalha, A. M. S, \& Chow, T. V. V. (2012). The Effects of Writing Apprehension in English on the Writing Process of Jordanian EFL Students at Yarmouk University. International Interdisciplinary Journal of Education, 1(1): 6-14.

Alvarez, T. (2001). Textos Expositivo-Explicativors y Argumentativos [Argumentative and Expository-Explanation Texts]. Barcelona, ES: Octaedio. 
The Students' Problems and Solutions in Writing

Aydinoglu,N. (2014). Gender in English Language Teaching Coursebooks. 14th International Language, Literature and Stylistics Symposium. Procedia - Social and Behavioral Sciences. 158, 233 - 239

Ariyanti, A. (2016). Shaping Students' Writing Skills: The Study of Fundamental Aspects in Mastering Academic Writing. Indonesia. J. EFL. Linguist, 1 (1), 63-77.

Aunurrahman, A., Hamied, F. A \& Emilia, E. (2016). Exploring an Academic Writing Class in an Indonesian University Context. Journal of Language and Literature, 11(1), 1-11.

Bakry, M. S., \& Alsamadani, H. A. (2014). Improving the Persuasive Essay Writing of Students of Arabic as a Foreign Language (AFL): "Effects of Self-Regulated Strategy Development," in $4^{\text {th }}$ World Conference on Educational Technology Researchers, WCETR, 182, 89-97.

Byrne, D. (1995). Teaching Writing Skills. Sixth Impression. Singapore: Longman Publisher.

Chala, P. A. \& Chapeton, C. M. C. (2013). The Act of Writing as a Situated Social Practice: Going beyond the linguistic and the textual. Colomb. Appl. Linguist. J. 15 (1), 25-42.

Chapter 1. (in press). United Nations Chapter 1: Purposes and Principles. Retrieved 12 October 2020 from from https://www.un.org/en/sections/un-charter/chapter-i/index.html

Cheng, Y. S. (2004). A Measure of Second Language Writing Anxiety: Scale Development and Preliminary Validation. Journal of Second Language Writing, 13(4):313-335.

Creswell, J. W. (2012). Educational Research: Planning, Conducting, and Evaluating Quantitative and Qualitative Research $\left(4^{\text {th }}\right.$ ed). Boston: Pearson.

Davis, J \& Liss, R. (2005). Effective Academic English. New York: Oxford University Press.

Ferretti, R. P., Andrews-Weckerly, S., \& Lewis, W. E. (2007). Improving the Argumentative Writing of Students with Learning Disabilities: Descriptive and Normative Considerations. Reading \& Writing Quarterly, 23(3), 267-285. https://doi.org/10.1080/10573560701277740

Ibnian, S. S. K. (2017). Writing Difficulties Encountered by Jordanian EFL Learners. Asian Journal of Humanities and Social Studies, 5(3). 197-206. Retrieved 10 October 2020 from https://www.ajouronline.com/index.php/AJHSS/article/view/4785

Islam, K.M.B. (2018). Issues in English Language Teaching: Gender in Language Education. Intellection: A Bi-annual Interdisciplinary Research Journal. 4 (2), 1-8.

Ka-kan-dee, M., \& Kaur, S. (2015). Teaching Strategies Used by Thai EFL Lecturers to Teach Argumentative Writing. Procedia - Social and Behavioral Sciences 208, 143 156.

Karyuatry, L. (2018). Grammarly as a Tool to Improve Students' Writing Quality: Free Online-Proofreader across the Boundaries. JSSH (Jurnal Sains Sosial dan Humaniora), 2(1), 83-89.

Kuhn, D. (1991). The Skills of Argument. Cambridge, UK: Cambridge University Press.

Levine, M. (1998). Developmental Variation and Learning Disorders. 2nd Edition. Educators Pub. Service Hardcore.

Nippold, M. A., \& Ward-Lonergan, J. M. (2010). Argumentative Writing in Pre-adolescents: The Role of Verbal Reasoning. Child Language Teaching and Therapy, 26(3), 238248.doi:10.1177/0265659009349979.

Norton, B., \& Pavlenko, A. (2004). Addressing Gender in the ESL/EFL Classroom. TESOL Quarterly, 38(3), 504-514. doi:10.2307/358835

JELTL (Journal of English Language Teaching and Linguistics), 5(3), 2020 
Lestari Setyowati et al.

Qin, J., \& Karabacak, E. (2010). The Analysis of Toulmin Elements in Chinese EFL university argumentative writing. System, 38(3), 444-456.

Qomariah, D N. (2019). Persepsi Masyarakat Mengenai Kesetaraan Gender Dalam Keluarga. Jurnal Cendekiawan Ilmiah PLS. 4 (2), 52-58.

Rahmatunisa, W. (2014). Problems faced by EFL learners in writing argumentative essay. English Review: Journal of English Education, 3(1), 41-49

Rezaei, M. \&Jafari, M. (2014). Investigating the Levels, Types, and the Cause of Writing Anxiety among Iranian EFL Students: A Mixed Method Design. Procedia-Social and Behaviour Sciences, 98, 1547. https://doi.org/10.1016/j.sbspro.2014.03.577

Rivers, W. M., (1981). Teaching Foreign Language Skill. Washington: The University of Chicago.

Setyowati, L. (2016). Analyzing the Students' Ability in Writing Opinion Essay using Flash Fiction. Journal of English Language Teaching and Linguistics (JELTL). e-ISSN: 25026062, p-ISSN: 2503-1848. Vol.1(1): 79-92.

Setyowati, L., Sukmawan, S., \& Latief, M. A. (2017). Solving the Students' Problems in Writing Argumentative Essay Through the Provision of Planning. Celt: A Journal of Culture, English Language Teaching \& Literature, 17(1), 86-102.

Setyowati, L. Sukmawan, S., \& El-Sulukiyyah, A.A. (2020). Write Down Your Thought: Essay Writing for EFL Learners. Sidoarjo: Delta Pijar.

Solikhah, I. (2017). Linguistic Problems in English Essay by EFL Students. Indonesian Journal of Language Teaching and Linguistics IJOLTL, 2(1): 31-44.

Sukmawan, S., Setyowati, L., \& Nurmansyah, A. (2017). Mendayagunakan genre sastra flash fiction untuk menulis teks argumentasi. Jurnal Ilmiah Edukasi \& Sosial, 6(1), 8495.

Sunderland. J. (1992). Gender in the EFL classroom. ELT Journal 46(1), 81-91

Toba, R., Noor, W. N., \& Sanu, L.O. (2019). The Current Issues of Indonesian EFL Students' Writing Skills: Ability, Problem, and Reason in Writing Comparison and Contrast Essay. Dinamika Ilmu, Vol. 19 (1): 57-73.

The Ministry of Demography, Women Empowerment, and Child protection of Indonesia/Bappenas, (2014). Pembangunan Kesetaraan Gender Background Study RPJMN III (2015 - 2019). Retrieved 14 October 2020 from https://www.bappenas.go.id /files/7014/0850/2296.

United Nations. (in press). Gender Equality. Retrieved 10 October 2020 from https://www.un.org/en/sections/issues-depth/gender-equality/

Wahyuni, S., \& Umam, M. K. (2017). An Analysis on Writing Anxiety of Indonesian EFL college learners. JEELS (Journal of English Education and Linguistics Studies), 4(1), 105-128. 